\title{
Final planned overall survival (OS) from OPTiM, a randomized Phase III trial of talimogene laherparepvec (T-VEC) versus GM-CSF for the treatment of unresected stage IIIB/C/IV melanoma (NCT00769704)
}

\author{
Robert HI Andtbacka ${ }^{*}$, Frances A Collichio ${ }^{2}$, Thomas Amatruda ${ }^{3}$, Neil Senzer ${ }^{4}$, Jason Chesney ${ }^{5}$, Keith Delman ${ }^{6}$, \\ Lynn Spitler ${ }^{7}$, Igor Puzanov ${ }^{8}$, Sanjiv Agarwala ${ }^{9}$, Mohammed Milhem ${ }^{10}$, Kevin Harrington ${ }^{11}$, Mark Middleton ${ }^{12}$, \\ Ai Li ${ }^{13}$, Mark Shilkrut ${ }^{13}$, Robert Coffin ${ }^{14}$, Howard Kaufman ${ }^{15}$
}

From Society for Immunotherapy of Cancer 29th Annual Meeting

National Harbor, MD, USA. 6-9 November 2014

\section{Background}

$\mathrm{T}$-VEC is an oncolytic immunotherapy derived from herpes simplex virus type- 1 designed to selectively replicate within tumors and to produce GM-CSF to enhance systemic antitumor immune responses. OPTiM, a randomized Phase III trial of T-VEC vs GM-CSF in patients with unresected melanoma with regional or distant metastases met the primary objective of an improvement in durable response rate (response lasting continuously for $\geq 6$ months) with T-VEC versus GM-CSF ( $16 \%$ vs $2 \%$, respectively; $P<0.001)$. Most common adverse events with $\mathrm{T}$-VEC were fatigue, chills, and pyrexia. No $\geq$ grade 3 adverse events occurred in $\geq 3 \%$ of patients in either arm (Andtbacka et al., J Clin Oncol 2013,32[suppl]:LBA9008). At the primary analysis (PA) of secondary OS endpoint, with median follow-up of 44 (range, 32-59) months and 189 events in the T-VEC arm and 101 events in the GMCSF arm, median (95\%CI) OS was 23.3 (19.5-29.6) months for T-VEC and 18.9 (16.0-23.7) months for GM-CSF (hazard ratio $[\mathrm{HR}]=0.79 ; 95 \% \mathrm{CI}=0.62-1.00 ; P=0.051$ ) (Kaufman et al., J Clin Oncol 2014,32[suppl]:9008a). Aplanned analysis of OS at 3 years from the last randomization is presented here.

\section{Methods}

Eligible patients were $\geq 18$ years old; had ECOG performance status (PS) $\leq 1$; unresectable melanoma stage IIIB/C/IV; injectable cutaneous, subcutaneous (SC) or nodal lesions; $\mathrm{LDH} \leq 1.5 \mathrm{X}$ upper limit of normal; $\leq 3$ visceral lesions (excluding lung), none $>3 \mathrm{~cm}$. Patients were randomized 2:1 to intralesional T-VEC (initially $\leq 4 \mathrm{~mL}$ $\mathrm{x} 10^{6} \mathrm{pfu} / \mathrm{mL}$, then after $3 \mathrm{wks}, \leq 4 \mathrm{~mL} \times 10^{8} \mathrm{pfu} / \mathrm{mL}$ $\mathrm{q} 2 \mathrm{w})$ or SC GM-CSF $\left(125 \mu \mathrm{g} / \mathrm{m}^{2} \mathrm{qd} \times 14 \mathrm{ds} \mathrm{q} 4 \mathrm{w}\right)$.

\section{Results}

Of 436 patients in the intent-to-treat analysis, 295 (68\%) patients received T-VEC and 141 (32\%) patients received GM-CSF; 57\% were men; median age 63 yrs. At time of the final OS analysis with median follow-up of 49 months [range, 37-63], only 1 additional event occurred (T-VEC arm). Median $(95 \% \mathrm{CI})$ OS was 23.3 months $(95 \% \mathrm{CI}=$ 19.5-29.6) for T-VEC and 18.9 months (16.0-23.8) for GMCSF; HR $=0.80$ (95\%CI $=0.62-1.01), P=0.06$ (descriptive). Five-year survival for the T-VEC arm was $33.4 \%(95 \% \mathrm{CI}=$ 27.7-39.2). T-VEC effect on OS was most pronounced in patients with stage IIIB/C/IVM1a melanoma $(\mathrm{HR}=0.57$; $95 \% \mathrm{CI}=0.41-0.81, P=0.001$ [descriptive] $)$ and in patients with treatment-naive disease $(\mathrm{HR}=0.52 ; 95 \% \mathrm{CI}=$ 0.36-0.75, $P<0.001$ [descriptive]).

'Huntsman Cancer Institute, Salt Lake City, UT, USA

Full list of author information is available at the end of the article 


\section{Conclusions}

With $>4$ years of median follow-up for survival, a persistent relevant OS effect was demonstrated with further followup. Long-term follow-up continues in the registry trial (NCT02173171). T-VEC represents a novel potential therapy for patients with regionally and distantly metastatic melanoma.

\section{Authors' details}

'Huntsman Cancer Institute, Salt Lake City, UT, USA. ${ }^{2}$ The University of Carolina at Chapel Hill, Chapel Hill, NC, USA. ${ }^{3}$ Minnesota Oncology, MN, USA. ${ }^{4}$ Mary Crowley Cancer Research Center, TX, USA. ${ }^{5}$ University of Louisville, Louisville, KY, USA. ${ }^{6}$ Emory University, Atlanta, GA, USA. ${ }^{7}$ Northern California Melanoma Center, San Francisco, CA, USA. ${ }^{8}$ Vanderbilt University Medical Center, Nashville, TN, USA. ${ }^{9}$ St. Luke's University Hospital \& Health Network, Bethlehem, PA, USA. ${ }^{10}$ University of lowa, lowa City, IA, USA. ${ }^{11}$ The Institute of Cancer Research/The Royal Marsden Hospital, London, UK. ${ }^{12}$ National Institute for Health Research Biomedical Research Centre, London, UK.

${ }^{13}$ Amgen Inc, Thousand Oaks, CA, USA. ${ }^{14}$ Amgen, Woburn, MA, USA.

${ }^{15}$ Rutgers Cancer Institute of New Jersey, New Brunswick, NJ, USA.

Published: 6 November 2014

doi:10.1186/2051-1426-2-S3-P263

Cite this article as: Andtbacka et al:: Final planned overall survival (OS) from OPTiM, a randomized Phase III trial of talimogene laherparepvec (T-VEC) versus GM-CSF for the treatment of unresected stage IIIB/C/IV melanoma (NCT00769704). Journal for ImmunoTherapy of Cancer 20142 (Suppl 3):P263.

Submit your next manuscript to BioMed Central and take full advantage of:

- Convenient online submission

- Thorough peer review

- No space constraints or color figure charges

- Immediate publication on acceptance

- Inclusion in PubMed, CAS, Scopus and Google Scholar

- Research which is freely available for redistribution

Submit your manuscript at www.biomedcentral.com/submit 